\title{
Charles Bowden
}

\section{Foreword SILENT LONG ENOUGH}

Ifrst met the Border Patrol in the early 1980s because I had decided to break the law. At the time, I worked for a daily paper in Tucson, Arizona, and I was dismayed by scant coverage of Mexican migrants who died crossing the desert in summer. I decided to learn how the Border Patrol worked and started hanging with the agents at Tacna, an isolated station in western Arizona that faced an uninhabited zone of thousands of square miles that ran up against the border. That is when I came to know some of the people in this book. And I decided I needed someone to go with me on my journey. So I called the man who created this book, Bill Broyles. On the night of June 21 we crossed from Sonora with a bunch of Mexicans, a walk that totaled forty-five miles. We staggered out of the desert the next morning and we felt deep pain. The Mexicans had to keep going toward their dreams of jobs and a future, and they had to keep hiding from the Border Patrol.

Since then, the Border Patrol has grown huge, the migration has become the largest one on earth, and the work done by the Border Patrol has remained a mystery to the public. This book should clear up what it feels like to patrol the border and give the reader a real sense of the people who do this work. It has been a labor of love on the part of Broyles and Mark Haynes and, to my knowledge, it is unique. Here you meet the people of the Border Patrol without anything standing between you and their stories.

They are decent people doing a thankless job, mainly trying to stop a migration of the poor from the utter ruin of Mexico. Sometimes they get hurt and sometimes they save people from death in the desert. But almost always, they are props used by proponents and opponents of the migration. Because of the discipline of the service, they are seldom allowed to speak out.

Now we can hear their voices. And I guarantee you are going to be 


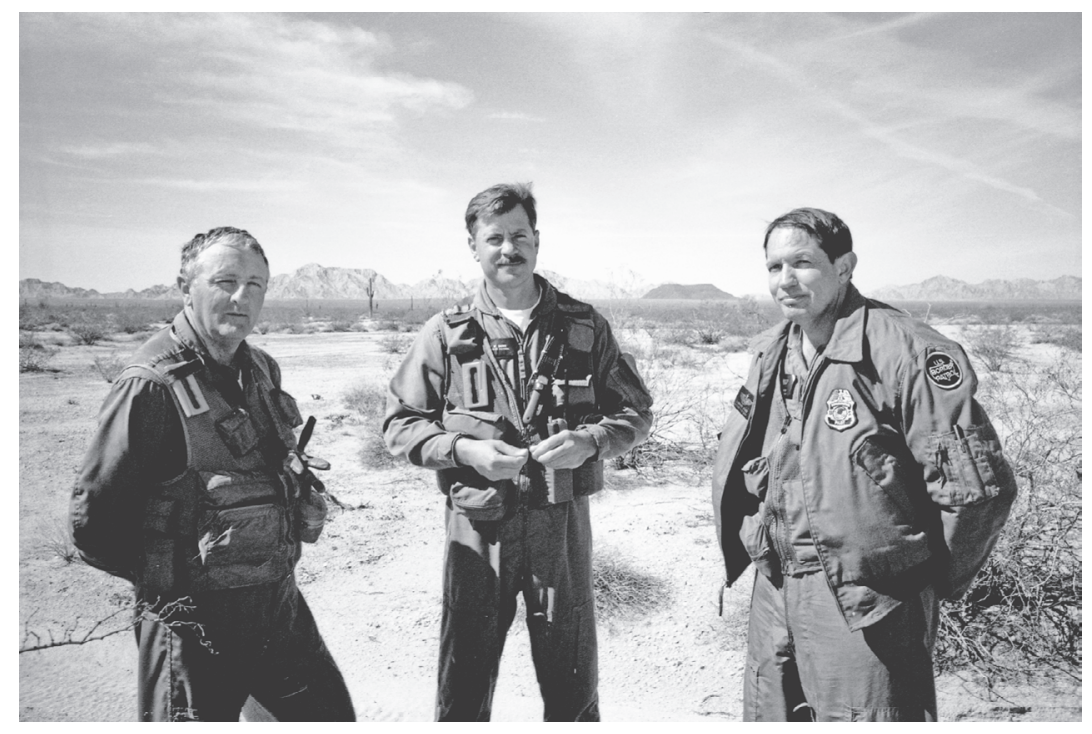

U.S. Border Patrol pilots Hank Hays, Joe Dunn, and Howard Aitken near the line. Photo by Bill Broyles, 1995.

surprised by what they say. You'll meet an agent whose father used illegal labor on his farm and cut his son off for years when he joined the Border Patrol. You'll brush against the craft of tracking. You'll find a bunch of people who took the federal job because they needed the money and then discovered the job became their very life.

It is a strange kind of work where you are there alone and you are hunting people - men, women, and children - who are seeking to escape the doom of failing economies. And I can tell you from personal experience, regardless of your views on borders or the migration, you get caught up in the hunt. And you eventually get caught up in the fragments of lives that you meet in the deserts and mountains, the slivers of facts that people tell you about where they have come from and where they are heading. I remember when I first hooked up with the Border Patrol they caught two teenage boys who had walked fifty miles across the desert in flip-flops. At such moments, you ask yourself if you could possibly pull off such a trek and you suddenly realize how fierce the conditions must be at home to propel a couple of kids into such a journey.

Now the world is changing. There are almost twenty thousand people in the Border Patrol, surveillance drones fly in the sky, a huge wall is going up on the line. Mexico is convulsed with poverty and violence, and at least 10 
percent of its people now live illegally in the United States. And the same thankless job goes on all along the line. It's time to learn what it takes to police our border and what it costs the people who do the work.

They've been silent long enough.

Charles Bowden is the author of five books published recently by the University of Texas Press: Inferno, Exodus, Trinity, Dreamland, and The Charles Bowden Reader. Or you may know him from his numerous articles in Harper's, GQ, Esquire, Texas Monthly, Arizona Highways, and newspapers, or his two dozen other books, including Killing the Hidden Waters (1977), Blue Desert (1986), Juárez: The Laboratory of Our Future (1998), and Some of the Dead Are Still Breathing (2009). 
THIS PAGE INTENTIONALLY LEFT BLANK 
DESERT DUTY 
THIS PAGE INTENTIONALLY LEFT BLANK 